\title{
The changing nature of the Australian electricity industry
}

The electricity supply industry has historically offered a homogenous good supplied via economically regulated transmission and distribution networks. Competition was introduced into the contestable generation and retail supply chain components as part of the 1990s Hilmer reform process. After a century of incremental technological developments, the industry is now being transformed by new distributed energy technologies and a global focus on reducing anthropogenic greenhouse gas emissions. Policy makers did not anticipate these changes. A number of key reforms are likely to be required. These include: assessing whether the return on capital provided to network operators is appropriate given changing economic conditions; determining the role of competition in the provision of 'behind the meter' energy services; and integration of climate change policy with wholesale energy market design.

Keywords: economic regulation; electricity; climate change; industries JEL Codes: N00; L94; Q41; Q54

\section{Introduction}

The electricity industry has historically had three supply chain components: generation (i.e. power stations), transmission and distribution (i.e. poles and wires) and retail supply (marketing, customer services and billing). For most of the $20^{\text {th }}$ century these functions were aggregated together within vertically integrated government-owned state electricity commissions. The industry was deregulated as part of the Hilmer microeconomic reforms of the 1990s with the competitive components (electricity generation and retailing) separated from those with monopoly characteristics (transmission and distribution).

Technology is fundamentally changing the nature of the electricity industry. Since 2008, the cost of installing household solar PV has declined by around $80 \%$ (Simshauser 2014). Around one in four residential properties is now operating its own generation in many Australian jurisdictions. The once homogenous product that is grid electricity supply is now competing with the "partial grid substitute' that is embedded generation. In the future, full grid substitution may become an option for some consumers with the deployment of battery storage and in-home energy management systems.

This paper examines how the electricity industry has evolved and the consequential policy reforms that may be required. It is structured as follows: Section 2 provides a brief outline of the history of the Australian electricity market; Section 3 discusses the role of monopolistic networks and competitive markets given the emergence of new energy technologies; the consequences of climate change policy for the electricity market are presented in Section 4; and brief concluding remarks provided in Section 5. 


\section{A brief outline of the history of the Australian electricity industry}

\subsection{Post Second World War to the mid-1990s}

The construction of large thermal power stations utilising relatively low-cost Australian coal and gas resulted in significant reductions in real electricity prices as scale economies were extracted. Installed generation capacity increased from around $3 \mathrm{GW}$ in 1955 to $30 \mathrm{GW}$ in the mid-1990s. The industry expanded through the utilisation of centralised generation that produced large volumes of energy transported over relatively long distances through a transmission and distribution system. Local and distributed generation were largely abandoned. ${ }^{1}$ From a pricing perspective, there are two distinct trends worth noting. Up until the late 1970s real electricity prices fell significantly as economies of scale were utilised. In the early 1980s, however, stateowned electricity commissions invested heavily in new generation capacity which resulted in material price increases..

\subsection{Mid-1990s to 2010: The Hilmer reforms}

In the period between 1995 and 2010, the National Competition Policy reform process resulted in the introduction of market competition for electricity generation and energy retailing. Stateowned electricity commissions disaggregated their power generation, transmission grid, distribution network and retail supply functions. In some states these newly created businesses were also privatised, but this occurred gradually. Economic regulation of network businesses was implemented to prevent monopolistic behaviour and pricing. The 'horizontal' and 'vertical' structural reforms are shown in Figure 1.

\section{Figure 1: 'Vertical' and 'horizontal' structural reform}

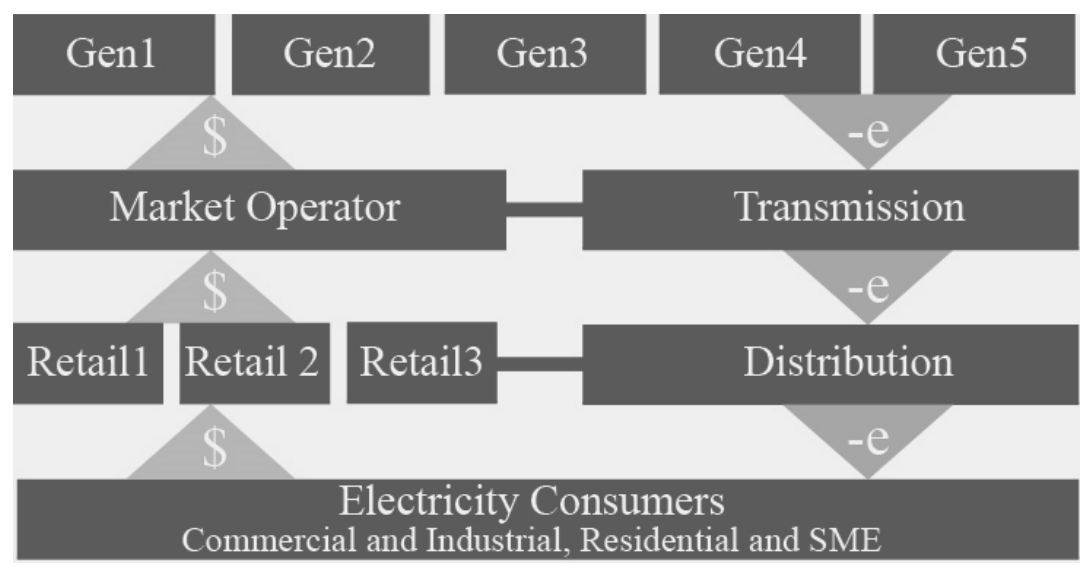

Source: Simshauser (2014)

The creation of the wholesale National Electricity Market (NEM) was a key microeconomic reform. The NEM wholesale market is an 'energy-only' market. Generators are only paid for the energy they generate, not the 'firm' capacity they make available to ensure system reliability and security. Prices during 'off-peak' periods tend to reflect short-run marginal costs of 'baseload' power generation, while prices at 'peak' periods reflect higher marginal costs of 'peaking plant' and can increase by around $25,000 \%$ to a cap of around $\$ 14,000$ per megawatt-hour (MWh). In theory, this allows heavy fixed capital costs to be recovered over the business cycle.

\footnotetext{
${ }^{1}$ In contrast, the earlier development of electricity systems often relied upon local generation (e.g. White Bay Power Station in inner Sydney).
} 
The introduction of retail competition was staged through a scheduled timetable to ensure an orderly transition. This process commenced from the mid-1990s, and was completed in Victoria and New South Wales in 2002, South Australia in 2003, and Queensland in 2007. Retail pricing deregulation was only implemented after competition had been deemed 'effective' as determined by the Australian Energy Market Commission (AEMC) under the Australian Energy Market Agreement.

The Hilmer Reforms were promoted by governments and the electricity industry itself as having delivered significant savings for consumers through improvements in allocative efficiency (see Parer, 2002 and Abbott, 2002). Not all economists agreed that the reforms had produced real and lasting benefits, however, with Quiggin (1997), Quiggin (2001), Beder (2003), Chester (2006), Beder (2012) and Quiggin (2014) notable examples of dissenting viewpoints. From a pricing perspective, residential electricity tariffs remained relatively constant in real terms. Figure 2 shows real and nominal electricity tariffs in the overarching period from 1955 to 2008. While the creation of the NEM provided a platform for efficiencies to be extracted, it is arguable that the observable price trends were simply the result of the exhaustion of overcapacity built in the 1980s. 
Figure 2: History of electricity tariffs (NSW and QLD): 1955 to 2008

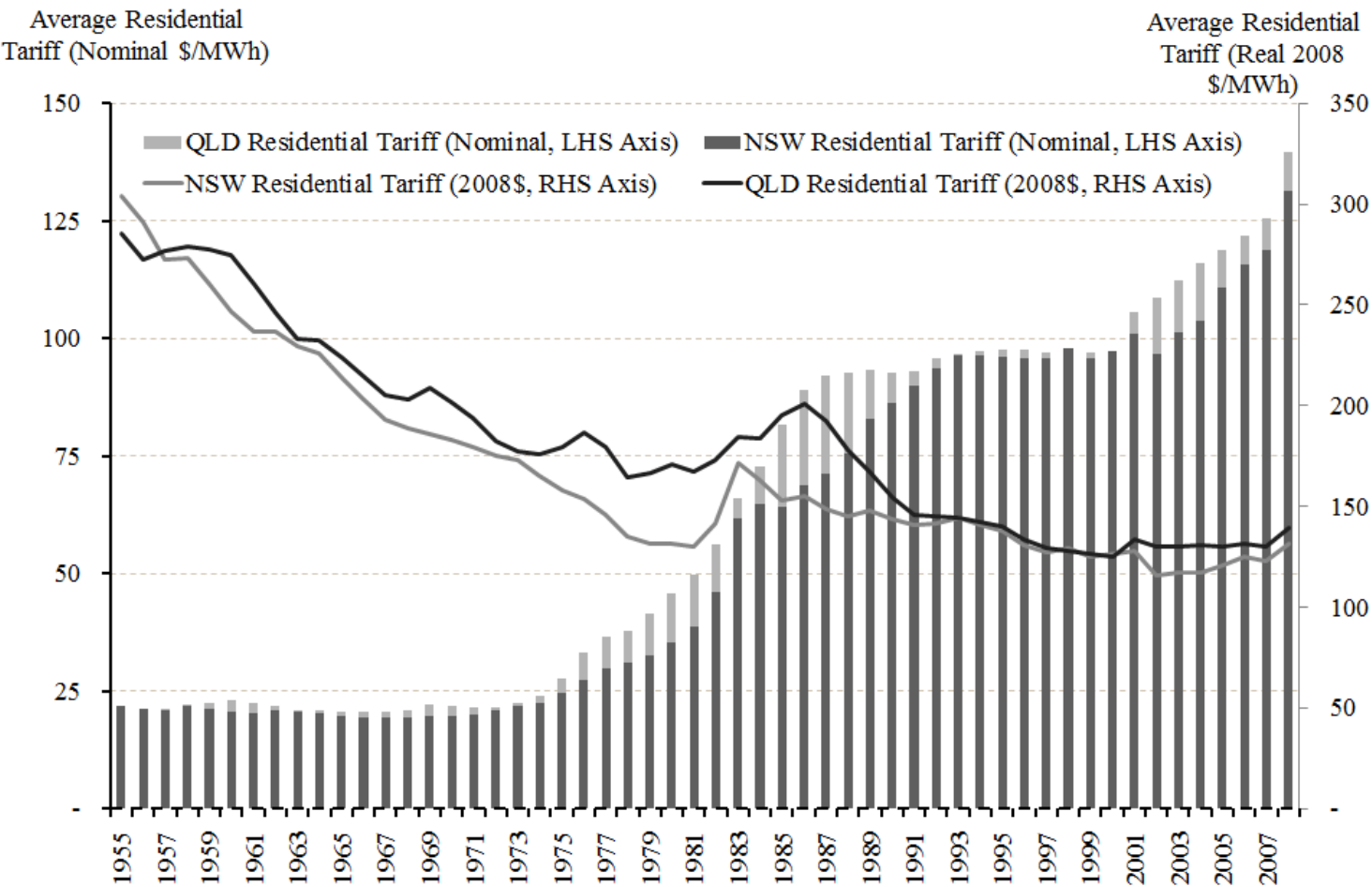

Source: Simshauser and Nelson (2013)

\subsection{The current decade}

From the early 2000s, it became clear that the NEM reform process had not adequately dealt to a range of issues: end-user tariff reform; appropriate network regulation; the evolution of technology; emergence of 'behind the meter' non-grid competition; and community expectations around anthropogenic greenhouse gas emission reductions. This is despite many of these issues being raised by the critics of the Hilmer reforms cited in the previous subsection (e.g. see Quiggin, 2001).

Microeconomic reform of pricing focused on the wholesale market but it is end-user pricing that influences consumer behaviour. The continued use of old accumulation-style metering technologies and two-part flat 'average cost' regulated network tariff settings prevented meaningful retail product reform. ${ }^{2}$ Air-conditioning penetration and embedded generation at the household level increased, and system utilisation factors fell., In Queensland for example, average demand increased by only $0.1 \%$ p.a. while peak demand increased by $2.1 \%$ p.a. from 2006 to 2014. Overarching NEM capacity utilisation fell from 54\% in 2009 to $47 \%$ in 2014. Infrastructure was being built but only utilised for small periods of the year. ${ }^{3}$ In our view, a primary driver of this reduced utilisation was the absence of cost reflective pricing and retail product innovation.

\footnotetext{
2 The literature suggests a shift towards Time-of-Use (ToU) or capacity-based demand tariffs. See Boituex (1949), Dessus (1949) and Houthakker (1951) as early examples and more recently Faruqui and Palmer (2011) and Fenwick et al (2014). Simshauser (2016) has provided quantitative evidence in relation to the Australian context. Tariff design is explored further in Section 3.

${ }^{3}$ Sydney experienced blackouts in its central business district (CBD) in 2003 and there were a series of distribution network-related blackout events in South-East Queensland (SEQ) in the first few months of 2004. As a result of these events, policy makers sought to tighten standards. They shifted from 'probabilistic risk-based' electricity network planning to a 'deterministic N-1' methodology. The tightening of these standards led to a large increase in capital spending on electricity networks. Total network assets in some states more than doubled from $\$ 27.6$ billion to $\$ 60.8$ billion. Quiggin (2014) explores the manifest failures in the regulatory framework that
} 
led to this situation, but put simply, it may be suggested that policy makers overreacted to reliability and security of supply concerns by implementing measures that allowed electricity networks to 'overspend' relative to what was required.

Page 5 
The absence of meaningful electricity metering and product market reform, together with divergent peak and underlying demand growth outcomes created conditions akin to an 'energy market death spiral'. A 'death spiral' is described succinctly by Severance (2011, p. 13):

$\therefore$..a utility commits to build new equipment. However, when electric rates are raised to pay for the new plant, the rate shock moves customers to cut their kWh use. The utility then raises its rates even higher-causing a further spiral as customers cut their use even more. In the final stages of that death spiral, the more affluent customers drastically cut purchases by implementing efficiency and on-site solar power, but the poorest customers have been unable to finance such measures..'

Evidence in Australia indicates that the NEM may have indeed experienced conditions akin to those described by Severance (2011) above. Figure 3 shows the significant increase in grid-based bills as prices roughly doubled between 2010 and 2015 yet average household consumption declined by $22 \%$.

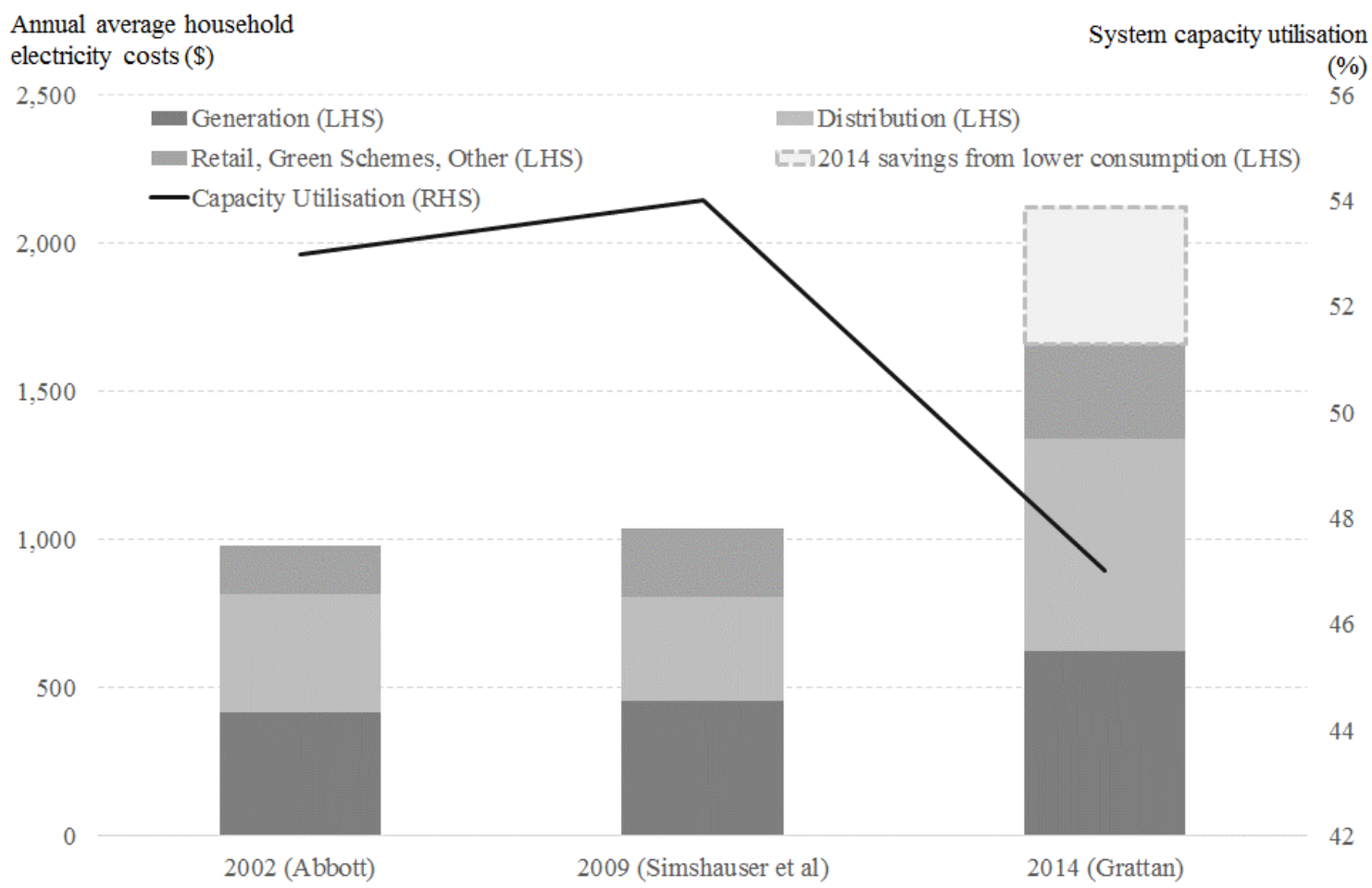

Source: Orton and Nelson (2015)

In the Australian context, 'average cost' pricing of energy, not capacity, assisted with the uptake of solar PV (see Simshauser, 2016). Total installed embedded solar PV capacity now exceeds 4 $\mathrm{GW}$ and over 1.5 million Australian households have installed embedded generation. Pricing reform is important to facilitate efficient investment decisions in existing, new and emerging technologies through the creation of pricing arbitrage (i.e. utilising a battery to store excess solar production for use later at times of peak demand). This is particularly important as new technologies are acting as a 'partial grid substitute'. Pricing reform should no longer be considered within the prism of 'microeconomic reform' but as a key element required to facilitate the efficient transition of a purely centralised electricity system to a bi-directional interconnected network that incorporates large-scale decarbonised energy production and embedded generation, storage and energy management systems. 
Climate change policy has also had a material impact on energy markets during the past decade. A proliferation of new public policies aimed at encouraging the adoption of new supply options with lower greenhouse gas emission profiles added significantly to the existing generation capital stock. At a peak, there were six policies in place to drive capital substitution or addition, including: the NSW Greenhouse Gas Abatement Scheme (GGAS); the Large-Scale Renewable Energy Target (LRET); the Small-Scale Renewable Energy Target (SRES); the QLD 18\% Gas Scheme; various energy efficiency policies (e.g. Victorian Energy Efficiency Target or VEET); and premium solar feed-in tariffs (PFiT). A carbon price was also established through the Clean Energy Future package but then repealed within a three-year window. ${ }^{5}$

The lack of integration of these policies with energy market reform has produced unintended consequences. South Australia has been disproportionately impacted due to its superior wind resource with much of the investment in renewables having been located in the state. While the system-wide blackout of 28 September 2016 has generated the most media discussion and resulted in an independent review (the Finkel review) ${ }^{6}$, there was significant discussion about the issues within South Australia well before this event (see Nelson and Orton, 2016, as one example). For brief periods in 2015, wind generation alone was up to $109 \%$ of underlying South Australian electricity demand. At times of peak demand, however, renewable generation was sometimes very low, necessitating the use of ageing thermal power stations within South Australia and the Heywood transmission interconnector to Victoria. Policy makers are beginning to discuss how better to integrate wholesale market design with climate change policy to ensure ageing 'firm' power plants are replaced with new infrastructure that complements renewables.

Pollitt and Haney (2013, p. 9) make the salient observation that when markets such as the NEM were liberalised, 'competitiveness was the overriding priority. Today, competitiveness, energy security and decarbonisation are the three main energy policy priorities'. The evidence presented above shows that the Australian experience is consistent with this observation. Section 3 and 4 discuss two key aspects of policy that will require further reform in this context: the role of networks and competitive markets; and better integration of wholesale market design and climate change policy.

\section{Emergence of a partial grid-substitute: the role of monopoly networks and competitive markets}

Some consumers no longer solely rely on the traditional electricity network to meet their demand for electricity. Consumers are able to meet their energy needs through full grid substitution (e.g. embedded solar generation and battery storage) or partial grid substitution (e.g. embedded solar, digital metering and advanced energy management systems). This requires policy makers to consider the suitability of several aspects of the existing regulatory framework. In our view, the most prominent questions relate to: the recovery (or not) of regulated monopoly network costs given ongoing partial grid substitution; pricing; and the role of competitive markets and monopoly networks in the provision of goods and services 'behind the meter'. 7

\footnotetext{
${ }^{4}$ Simshauser et al (2009) was available in working paper form in 2009/10 but published as Simshauser et al (2011).

${ }^{5}$ An anonymous reviewer made the important (and in our view, inarguable) observation that policy makers should have done a better job integrating energy and climate change policy given the Australian Government has been committed to addressing climate change since at least 1992 (with the development of the United Nations Framework Convention on Climate Change). Successive Commonwealth Governments have done a poor job in providing a coherent long-term national approach to addressing Australia's international climate change commitments.

${ }^{6}$ See http://www.scer.gov.au/sites/prod.energycouncil/files/publications/documents/Energy\%20Council\%20Communique\%20$\% 207 \% 20$ October\%202016.pdf for further details on the Finkel review. Accessed online on 28 October 2016.

${ }^{7}$ Interrelated aspects of these reforms were cited by the critics of the Hilmer reform process well before they manifested. This article has not addressed other important questions such as the existence of excess rates of return related to public/private differential rates of return on capital. Retail margins are also being questioned by many commentators (see Quiggin, 2014, as an example). Simshauser and Whish-Wilson (2016) discuss the economics of retail pricing. We contend that 'behind the meter' digital technology disruption will increasingly shift electricity from a homogenous good to a suite of heterogeneous services. This will act as a constraint on the ability to extract higher margins.
} 


\subsection{Recovery of network costs}

Section 2 highlighted the significant increase in network costs that have driven increases in residential and small business electricity tariffs since 2009, particularly in New South Wales and Queensland (see Figure 3). Australian Energy Regulator determinations made in the period between 2009 to 2011 allowed for increased investment of 46\%. The rationale for such a significant increase was to replace ageing assets, meet higher reliability standards and respond to forecasts of rising peak demand. Since 2011, regulatory determinations have resulted in efficient investment falling by $25 \%$. Replacement spending is now the primary driver of capital expenditure with $\$ 2.20$ of replacement infrastructure spending for every dollar of augmentation expenditure. Distribution network business regulated asset bases (RAB) and current and previous regulatory period investment are shown in Figure 4.

Figure 4: Investment spending and regulated asset bases of distribution network businesses

$$
\text { Investment }(\$ \mathrm{~m})
$$

16000

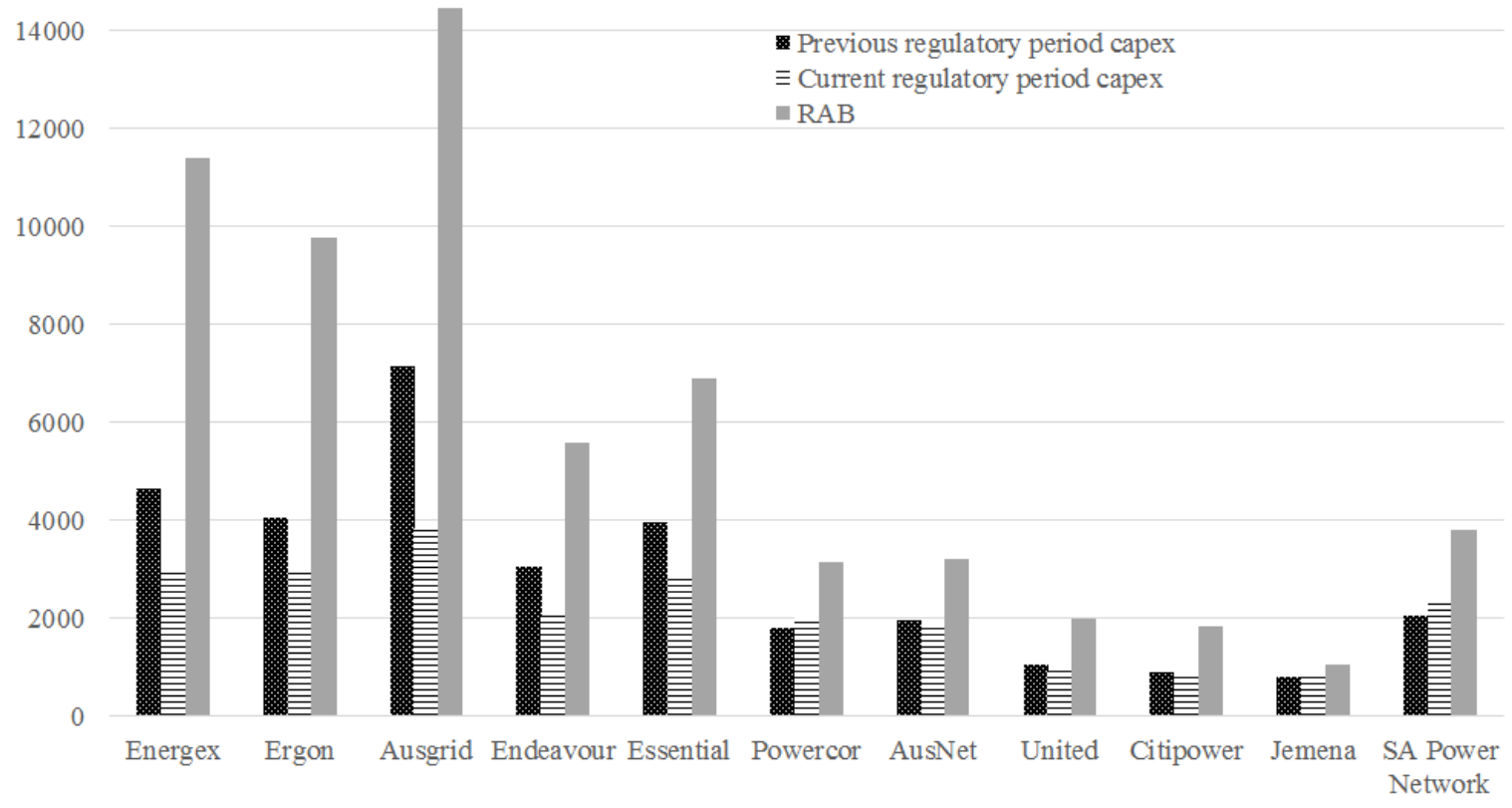

Source: Australian Energy Regulator (2015)

Perhaps unsurprisingly, productivity in New South Wales and Queensland distribution networks has been declining since the significant increase in capital allocation in 2009. Simshauser (2014) found that capital productivity in New South Wales and Queensland decreased by approximately $50 \%$ and $20 \%$ respectively between 2004/05 and 2012/13. Over the same time period, labour productivity fell by around $20 \%$. Both capital and labour productivity fell by substantially more than overall Australian capital and labour productivity. Mountain and Littlechild (2010) have proposed that government ownership of networks may have an impact on their efficient operation. 
Figure 5: Annual average household electricity costs with network cost breakdown

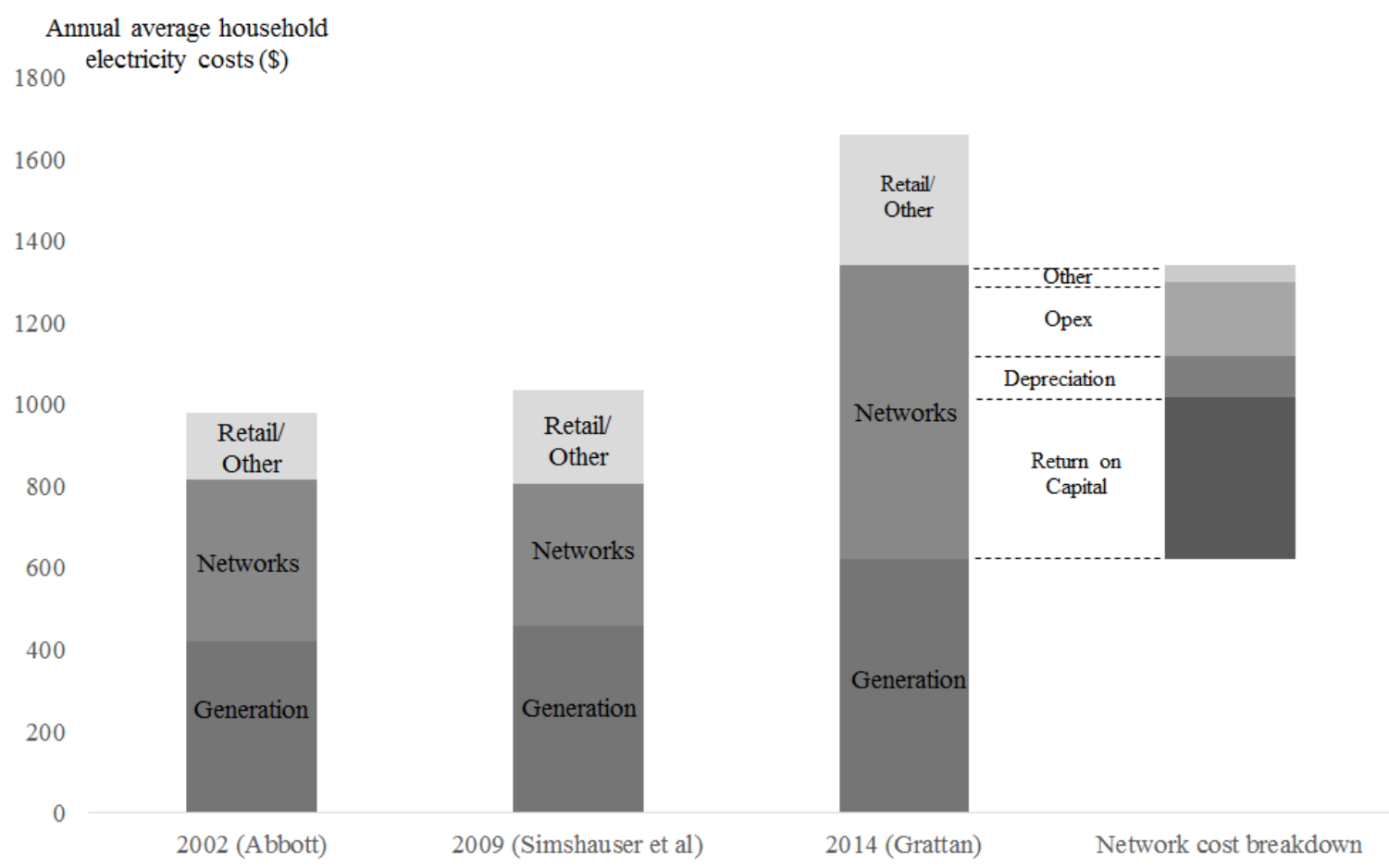

Source: Adapted from data in Orton and Nelson (2015) and AER (2015)

The substantial increase in network capital expenditure and declining productivity has resulted in network expenditure comprising around half of the average annual household electricity bill. Figure 5 expands upon Figure 3 with a breakdown of the components of network spending. It shows that the return on network capital alone represents around one-quarter of a household electricity bill. Given declining productivity and the continued substitution of network use through the proliferation of embedded generation, economic regulation may need to evolve.

Regulatory theory and practice in other industries is instructive. One of the most cited examples within the literature relating to emergence of competition within a once monopolistic and regulated market is the Market Street Railway ${ }^{8}$ streetcar utility in San Francisco in the 1940s. In this case, streetcar utilities were regulated businesses due to the lack of competing technologies for the same carriage service. The emergence of competition in the form of buses and individually-owned cars resulted in the business beginning to incur an accounting loss. The regulator (the Railroad Commission of California) permitted an increase in tariffs. Higher expected revenues derived from higher prices were offset by continued reductions in streetcar usage. A 'death spiral' had begun. The U.S. Supreme Court (1945) eventually found that tariffs could be set in a way that facilitated the company making an accounting loss:

'The due process clause has been applied to prevent governmental destruction of existing economic values. It has not and cannot be applied to insure values or to restore values that have been lost by the operation of economic forces.'

Graffy and Kihm (2014, p. 26) describe the situation succinctly: 'If market values decline in response to successful competition, utilities cannot simply look to their regulators to undo the impact of fundamental changes in market forces'.

\footnotetext{
${ }^{8}$ The legal proceedings are cited as Market St. Ry. Co. v. Railroad Commission (1945).
} 
In many ways, the situation described above could be applied to the electricity distribution businesses operating today. New technologies have resulted in a reduction in throughput revenue and so prices have been increased to ensure overall revenues remain intact. It will be important for society to consider who should bear the cost of network assets that are underutilised. It could be argued that there is an implied social contract (sometimes referred to as a 'regulatory compact') between society and regulated network businesses. Network businesses have benefitted from an exclusive service territory and a 'captive' customer base. However, network businesses have been constrained from earning monopoly profits by economic regulation. They have also been required to meet prescribed levels of service reliability. It is an open question, then, as to the equity of subsequently exposing such businesses to competitive market losses incurred through technology innovation. ${ }^{9}$ In the long-term, it is inarguable that consumers will object to paying higher tariffs for an underutilised network. Crawford (2015) provides some interesting perspectives on this issue.

A critical question seems to be whether networks will continue to be considered monopolists. For the time-being, they would appear to retain that status. Electricity is an essential service and there has been a broad universal right to connect to the distribution network. Competition for the network's services, in the form of distributed generation and storage, is partial and incomplete. The generation profile of rooftop solar can generally only satisfy a portion of a customer's demand for energy, and energy storage remains (for the time being) prohibitively expensive for most customers. Furthermore, the existing network remains the most economically efficient means for connecting physical flows of energy between connection points and thereby for transacting energy and accessing energy and ancillary services markets. ${ }^{10}$

\subsection{Tariff design}

In addition to likely reform of the overall level of revenue raised by networks, the composition of revenue in the form of tariff design is changing. The AEMC has introduced a new rule requiring electricity networks to progressively shift to 'cost-reflective tariffs'. The purpose of these reforms is to: ensure that customers are incentivised to optimise their peak demand rather than energy usage as peak demand is the driver of heavy fixed costs; and avoid cross-subsidisation by making the recovery of sunk costs more equitable (i.e. reduce cross-subsidies amongst various customer segments). By shifting tariffs to be more 'cost reflective', the 'death spiral' referred to in Section 2 becomes less likely. As a result of the AEMC directive, opt-in capacity tariffs (as opposed to energy based throughput tariffs) will be introduced in 2017. Demand tariffs are likely to drive efficient consumption, as well as more efficient investment in distributed energy (see Simshauser, 2016) ${ }^{11}$. Table 1 shows distribution network service providers are proposing different timeframes, structures and strategies for assignment of customers to the more 'cost-reflective' network tariffs being introduced in their service areas.

\footnotetext{
${ }^{9}$ A further question is whether it is in fact even in a network's own best interests to continue to recover stranded asset costs from an ever declining customer base. Levying increased fixed charges on customers in order to continue to recover historical expenditure on assets that are now materially underutilised may only drive further substitution and defection. It also has the potential to sharpen distributional impacts on low-income households.

10 The issue is not unique to Australia. CEPA (2016) discuss the evolution of regulatory frameworks in Australia, California (through the California Public Utilities Commission), New York (through the 'Reforming the Energy Vision' initiative) and the United Kingdom (through its RIIO initiative). CEPA (2016, p.iv) go on to state that, 'there is potential for network activities across transmission and/or distribution as a whole to be contestable, or contestable for some customers'.

${ }^{11}$ Also, see Brown et al (2015) for further discussion on treatment of sunk costs.
} 
Table 1: Cost reflective network tariffs from 2017

\begin{tabular}{|c|c|}
\hline Network business & Proposed tariff \\
\hline Ergon & Opt-in Seasonal Time-of-Use Energy and Seasonal Time-of-Use Demand tariffs \\
\hline Energex & Opt-in Demand tariff includes Hot Water Tariff for Demand customers. \\
\hline Ausgrid & $\begin{array}{l}\text { Opt-in Time-of-Use tariffs. From } 1 \text { July } 2018 \text {, all new customers assigned to Time-of-Use tariffs with opportunity to opt- } \\
\text { out to a transitional tariff. All existing customers with digital metering to be assigned to this transitional tariff on } 1 \text { July } \\
2018 \text {. }\end{array}$ \\
\hline Essential & $\begin{array}{l}\text { Time of Use tariff default for new customers, new Solar PV installations and metering upgrades. Opt-in to Demand-based } \\
\text { tariffs also available. }\end{array}$ \\
\hline Endeavour & $\begin{array}{l}\text { Opt-in Time of Use tariffs. All new customers with interval meters assigned to Time-of-Use tariffs from } 1 \text { July } 2018 \text { on } \\
\text { opt-out basis. }\end{array}$ \\
\hline ActewAGL & $\begin{array}{l}\text { Time-of-Use tariff default for all new residential and small business customers. Small business customers can opt-in to } \\
\text { Demand tariffs. Possible gradual introduction from } 1 \text { December } 2017 \text { of residential demand tariff. }\end{array}$ \\
\hline $\begin{array}{l}\text { Citipower. } \\
\text { Powercor, United } \\
\text { Energy, Jemena, } \\
\text { Ausnet }\end{array}$ & $\begin{array}{l}\text { Opt-in residential Demand Tariffs (not available in Ausnet service area until 2018). Opt-in Demand tariffs for all small } \\
\text { business customers consuming <60 MWh pa. United and Jemena: Demand tariffs mandatory for small businesses } \\
\text { consuming }>60 \mathrm{MWh} \text { pa. Powercor, CitiPower and Ausnet: transitional Demand tariff mandatory for small business } \\
\text { consuming }>60 \mathrm{MWh} \text { pa. Cost reflectivity of the transitional tariff will increase between } 2017 \text { and } 2022 \text {. }\end{array}$ \\
\hline $\begin{array}{l}\text { South Australia } \\
\text { Power Networks }\end{array}$ & $\begin{array}{l}\text { Opt-in cost-reflective residential Demand tariff. Opt-in 'fully' cost-reflective demand tariff for small business customers. } \\
\text { Mandatory assignment to transitional Demand tariff (50\% cost reflective Demand) for new 3-phase customers and } \\
\text { progressive increases in cost-reflectivity until } 2022 .\end{array}$ \\
\hline
\end{tabular}

Source: Distribution network businesses tariff statements 


\subsection{The role of competitive markets and monopolies}

The market for 'behind the meter' products and services shows every sign that it will continue to be strongly led by customer demand and preferences. Australian households lead the way in solar PV installations and installations continue to grow. Given Australia's restructured retail market, relatively high grid-based electricity bills, increased solar system installation sizes and poor load factors, Australian households may lead in the take-up of energy storage systems. New business models have emerged, such as those offering solar 'leasing' products. Some new products have a focus on enabling customers to share energy beyond the home - whether with other households, in facilitated markets or to support network operation. These products depend on grid access.

The opportunity to utilise 'behind the meter' distributed energy resources (DER) to support network operations and avoid network augmentations represents a potential scope economy. However, the potential to access these benefits are likely to constitute only one of many factors (and perhaps a minor one) driving a customer decision to invest in DER. Other drivers are likely to include the desire to reduce long-term personal energy bills, the pursuit of a degree of 'energy independence' and environmental considerations. In addition to network support services, opportunities to realise value beyond the home will also arise in wholesale and ancillary service markets.

The literature provides strong evidence for prohibiting monopoly distribution networks from operating in contestable 'behind the meter' products and services (see Whinston, 1990, as an example) ${ }^{12}$. Given the need for some degree of regulatory intervention to ensure monopolist networks are not impeding the development of contestable products and services, it is necessary to ask whether either 'structural separation' or 'ring-fencing' is appropriate. Goncalves et al (2010) outline a decision matrix for assessing whether structural separation or ring-fencing should be pursued:

(1) "Is there significant market power in the provision of access?"; (2) "Are there little vertical complementarities between services along the supply chain?"; and (3) "Is network separation a better regulatory tool than any other alternative?". A positive answer to all the questions implies that the regulator should consider network separation as a regulatory remedy.

Based upon the criteria, it would appear that stringent ring-fencing of network activities from contestable offerings of products and services is an appropriate outcome. Schwarcz (2014, p. 105) makes the case that, 'utility companies represent the easiest case for ring-fencing' and that 'the very fact of a utility company being a monopoly effectively creates a structural mandate for ringfencing.' In any event, the AER is proceeding with the implementation of stringent ring-fencing requirements for economically regulated network business. ${ }^{13}$ In our view this is a sensible outcome.

The preclusion of monopoly networks from operating 'behind the meter' does not rule out the realisation of network benefits. They can instead be procured from contestable service providers offering customers an integrated package of products and services. These service providers will have incentives to maximise the efficient use and deployment of 'behind the meter' installations in light of the range of drivers and potential value streams available and, importantly, the relative value that customers place on each of these. Contestability for network services may increase 'retail' competition as well with the entry of new firms.

12 Our thanks to an anonymous reviewer for substantial feedback on this section which has allowed for this stronger proposition to be included. 
Although there will be some transaction costs involved in network businesses procuring network support services from 'behind the meter' installations (rather than directly investing in these), it is clear that these costs would not outweigh the benefits of otherwise preserving the competitive neutrality of the market. And in fact, competition in the provision of network support services to networks may allow distribution businesses to procure these more cost effectively thereby allowing the more efficient fulfilment of network service obligations. ${ }^{14}$

\section{Climate change and wholesale market reform}

At the Conference of the Parties (COP) meeting of the United Nations Framework Convention on Climate Change (UNFCCC) in December 2015, all nations agreed to limit anthropogenic climate change to two degrees Celsius above pre-industrial averages (UNFCCC, 2015). Under this agreement, Australia has committed to reduce emissions by 26-28\% on 2005 levels by 2030. Given the commitment to achieving no more than 'two degrees' of warming, it is possible that such a target is inadequate. Assuming a linear reduction trajectory and a 'generous' share of a global carbon budget for Australia of around 10 gigatonnes of carbon dioxide equivalent between today and 2050, emissions may need to fall by up to $45 \%$ by 2030 (see Adams et al, 2014). The electricity sector will be a significant source of abatement as it comprises around one-third of Australia's national greenhouse gas inventory and other sectors may be unable to decarbonise within the same timeframe based upon current technology. Australia's emissions reduction commitments are likely to result in significant transformation of the Australian electricity industry.

\footnotetext{
13 The AER (2016, p. 11) has stated that: 'Ring-fencing is the identification and separation of business activities, costs, revenues and decision making within an integrated entity associated with a regulated monopoly service, from those that are associated with providing services in a competitive market. Ring-fencing therefore protects the long term interests of consumers more broadly by promoting competition in contestable markets.

14 It is important to understand the difference between the electricity industry and other industries in relation to structural separation and ring-fencing. The telecommunications literature is mixed with studies such as Crandall and Sidak (2002) and Howell et al (2010) generally against structural separation with Howell et al (2010, p. 392) stating that, 'competition between vertically integrated telecommunications providers would likely induce more efficient and sustainable investment and competition than would separation.' de Biji (2005) asserts that structural separation in telecommunications is only appropriate where local access is a persistent bottleneck. In comparison with the rail sector, Pittman (2005) argues that the electricity sector is better suited to structural separation of monopoly elements due to the greater proportion of costs and revenues in competitive sectors (which may increase over time if left to market forces).
} 
Australia does not have the policy tools in place to deliver the 26-28\% reduction in emissions by 2030 (see Nelson, 2015). Given the gap between Australia's commitments and the policies in place to achieve them, State governments are unsurprisingly implementing their own electricity sector decarbonisation policies. The Victorian and Queensland Governments, respectively, have committed to shifting their energy mix to $40 \%$ renewable by 2025 and $50 \%$ renewable by 2030 .

A review of climate change policy is scheduled to occur in 2017. There is significant discussion about the merits of 'carbon pricing' (see Freebairn, 2016 and Freebairn, 2014) and other policy instruments such as emissions intensive generation closure mechanisms (see Jotzo and Mazouz, 2015) and renewable energy investment policies. A 'carbon price' appears inherently difficult to implement given the intense political history related to introducing and then repealing the Clean Energy Future carbon price. Even if carbon pricing is implemented, Australian policy makers will need to consider whether such a scheme is 'linked' to other national schemes (e.g. the European Union ETS or a possible future Chinese ETS - see Jotzo and Loschel, 2014). If the objective of climate policy is to structurally decarbonise the Australian economy, internationally linked carbon pricing may not result in emissions mitigation in Australia and may actually defer the structural decarbonisation of the economy (see Adams et al, 2014 for modelling that demonstrates this point).

Least-cost modelling of the wholesale electricity market is instructive for demonstrating the challenge facing Australian policy makers. Utilising PLEXOS modelling ${ }^{15}$, Figure 6 shows the generation output in the NEM with a $27 \%$ emissions reduction target in place. Two distinct trends are worth noting. The first is the declining role of coal-fired power stations. The second is the significant investment in renewables that is required to reduce emissions consistent with achieving a $27 \%$ emissions reduction. Gas substitution for coal is forecast to play a relatively small role in Australia's decarbonisation to $2030 .{ }^{16}$ Around $12 \mathrm{GW}$ of new large-scale renewable capacity is required at a capital investment of approximately $\$ 23$ billion. Furthermore, around 11.5 GW of embedded small scale distributed solar PV is installed.

Figure 6: Least cost generation output with a $27 \%$ emissions reduction target

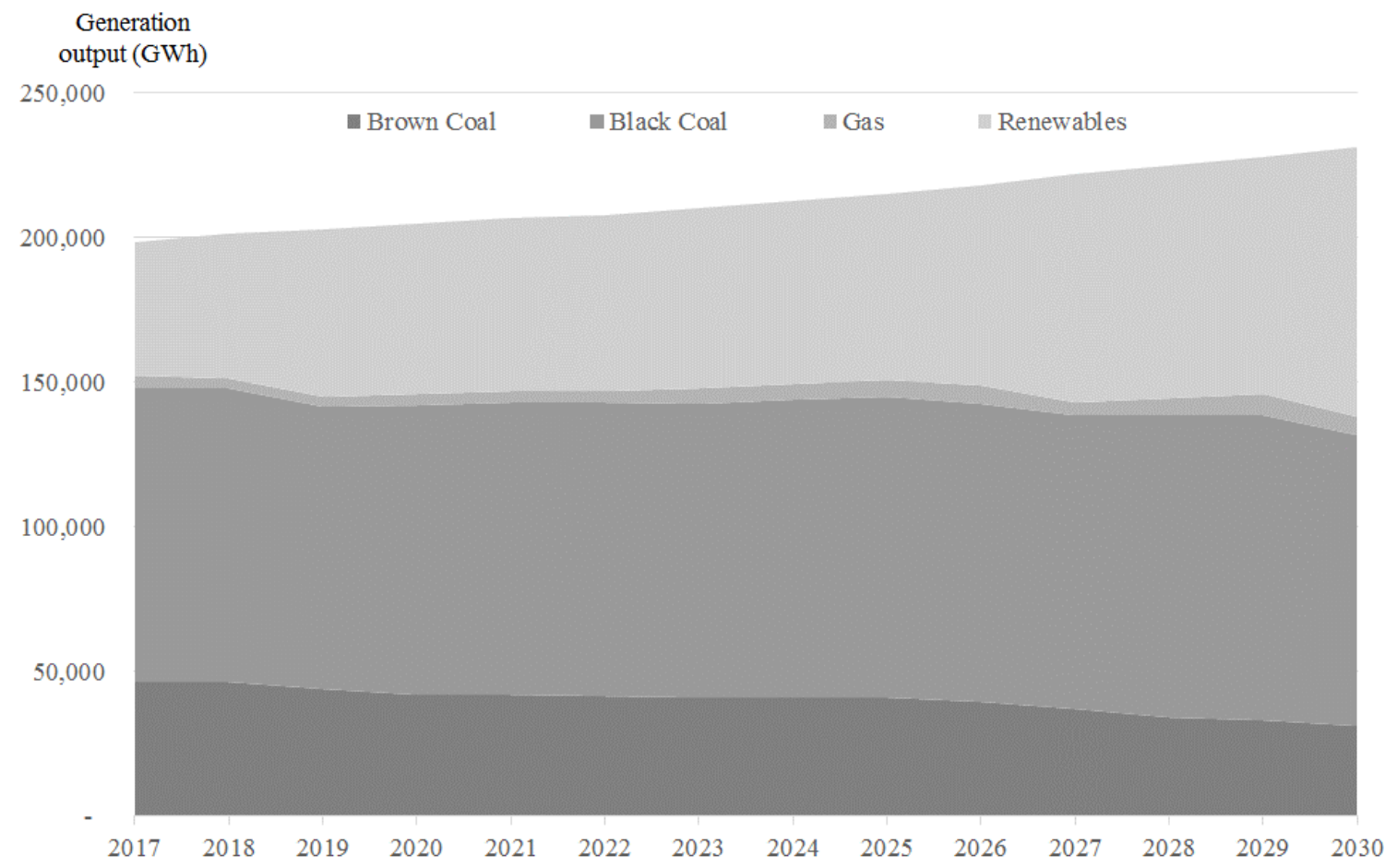


Figure 6 shows that irrespective of the policy instrument utilised, the least cost emissions reduction opportunities within the NEM are likely to be the deployment of renewables. ${ }^{17}$ As such, the trend towards the utilisation of renewable energy obligations to deliver emissions reductions does not appear to be inappropriate. With individual state governments pursuing their own renewable energy targets, it will be important for governments to develop a national approach to the stimulus of investment in new renewable energy capacity. ${ }^{18}$

Around three-quarters of the NEM's thermal (coal and gas) plant are older than their original design life. These plants will need to be replaced with low emissions capacity (such as renewables, peaking gas and advanced batteries) over the coming decades to ensure that system reliability is maintained..$^{19}$ However, due to the lumpy nature of capital investment and the potential for closure announcements to be made in a way that does not allow new capacity to be constructed before closure occurs, pricing outcomes are likely to reflect prolonged periods of 'famine' and 'feast'. ${ }^{20}$ There is a arguably a role for governments to establish policy that facilitates 'orderly' rather than 'disorderly' exit of emissions intensive aged power stations (see Nelson et al, 2015). A market-based closure policy (e.g. Jotzo and Mazouz, 2015) allows for asymmetric information (i.e. individual plant cost structures) to be discovered through pricing structures and may lead to more efficient decision making, but could lead to higher pricing volatility. While a regulatory closure model (e.g. based upon age) would arguably address political economy concerns around pricing volatility, it may not produce the most efficient outcome due to asymmetric information. Ultimately, policy makers should view a closure policy as both: an important means of securing energy supplies from modern generation equipment; and a way of reducing greenhouse gas emissions.

\footnotetext{
${ }^{15}$ For further information on the modelling approach, see Appendix 1.

${ }^{16}$ While Australia has significant gas reserves, the vast majority of $2 \mathrm{P}$ reserves are now allocated for export through a new LNG export industry in Gladstone, Queensland. There is insufficient gas available to allow for cost-effective substitution of gas for coal in power generation. Simshauser and Nelson (2015) provide a detailed explanation of the events that lead to this situation.

${ }^{17} \mathrm{We}$ acknowledge this is a controversial statement. While the previous footnote indicated that gas supplies are restricted at present, it may be that gas becomes readily available at lower costs (one market participant is currently proposing to build an LNG import facility - see http://riscadvisory.com/agl-eyes-lng-imports/). However, in our view there is a likely correlation between the strength of our generation mix results and the continued 'policy uncertainty' we discuss in this article. It will become inherently difficult in the future to bank combined-cycle gas plant (CCGT) as continued depletion of Australia's '2-degree carbon budget' at a higher than necessary rate (due to the lack of meaningful policies being in place) will result in a CCGT emissions profile being inconsistent with achieving the budget. This is worthy of future research.

${ }^{18}$ Some commentators are arguing for greater interconnection (i.e. transmission lines between markets) investment. We would urge policy makers to be cautious because regulated assets lock in long-term costs to consumers. As noted earlier in this paper, tightening of distribution network standards led to a large increase in capital spending on electricity networks. There is now discussion about 'gold plating' and 'overspending' on distribution network assets. As each state decarbonises its electricity supply, it may become more (not less) reliant upon local embedded generation. This could potentially strand new interconnection investment.

19 Even without a decarbonisation policy objective, wholesale prices would inevitably need to rise at some point in the future to the long-run marginal cost of new generation.

${ }^{20}$ See Nelson and Orton (2016) for a detailed explanation of the 'feast' and 'famine' pricing argument within the context of South Australia.
} 
Even with a 'closure' policy in place to address orderly capital withdrawal, policy makers will also need to assess whether new 'firm' capacity investment will be forthcoming. Pricing volatility is effectively the economic means by which 'energy-only' markets provide revenue adequacy for an 'optimal' generation mix. Heavy fixed costs associated with building power stations are recovered at times of peak electricity demand. But with the introduction of very low short-run cost renewable generation (i.e. the sun and wind are free) via climate-related public policies such as the 20\% Renewable Energy Target, pricing volatility must become extreme to ensure capital costs of firm complementary thermal generation or battery storage technologies can be recovered.

Table 2: Ratio of top $30 \%$ of prices relative to bottom $30 \%$ of prices

\begin{tabular}{c|cccc}
\hline & NSW & QLD & SA & VIC \\
\hline 2017 & 1.67 & 1.44 & 6.85 & 2.65 \\
2030 & 7.70 & 8.27 & 21.93 & 9.52 \\
\hline
\end{tabular}

Utilising the PLEXOS modelling referred to earlier, Table 2 shows the ratio between high and low wholesale electricity price periods is projected to increase by a factor of three if the Commonwealth Government's emissions reduction target of 26-28\% of 2005 levels by 2030 is to be achieved. A 2016 study by Riesz et al (2016) found that the NEM would require a market price cap of between $\$ 60,000$ to $\$ 80,000$ per MWh for revenue adequacy if the system was supplied by $100 \%$ renewable energy - six times higher than today. Prices would need to be able to increase by a factor of around 1,500 in half-an-hour.

Many economists have argued that pricing volatility is not a problem in itself because forward contract and derivative markets have evolved to allow participants to mitigate pricing volatility risk. This is certainly true with regard to the operation of existing generation infrastructure. In fact, markets are evolving to address the issues related to very low short-run marginal cost renewables. Table 3 shows the increase in the proportion of market revenue derived from the frequency control ancillary services (FCAS) market. These 'additional' markets may become more important as the proportion of renewable energy in the system grows.

Table 3: Proportion of market revenue from FCAS

\begin{tabular}{l|c|c}
\hline Region & $\begin{array}{c}\text { \% of market revenue from FCAS } \\
\text { (Sept 2015 to October 2016) }\end{array}$ & $\begin{array}{c}\text { \% of market revenue from FCAS (5 years to } \\
\text { September 2016) }\end{array}$ \\
\hline NSW & 0.50 & 0.20 \\
QLD & 0.44 & 0.20 \\
SA & 5.89 & 1.77 \\
TAS & 1.07 & 1.04 \\
VIC & 0.55 & 0.21 \\
\hline
\end{tabular}

However, Caplan (2012) and Nelson and Simshauser (2013) have demonstrated that investors in new power generation infrastructure will not rely on short-term spot or derivative markets. Longer-term instruments such as Power Purchase Agreements (PPAs) have evolved to match investor risk preferences with financial instrument design. As new renewable energy policies are introduced to delivery significant emissions reductions, policy makers may wish to consider how to incentivise appropriate investment in complementary 'firm' capacity. This could be as simple as requiring new renewable projects to demonstrate they have contracted (through the provision of a 'firm capacity right' certificate) for long-term provision of 'firm' capacity. Renewable generators would effectively become 'dispatchable' in a traditional 'energy-only' market and could sell forward derivative contracts, overcoming existing perceived limitations. ${ }^{21}$ 


\section{Concluding remarks}

This article has considered how the 1990s Hilmer microeconomic reform process of the electricity sector requires reassessment. Two aspects of the energy sector have fundamentally changed in the past decade: the emergence of a 'partial grid substitute' in the form of DER; and the need to reduce anthropogenic greenhouse gas emissions in a manner consistent with Australia's commitment to reduce emissions by $26-28 \%$ of 2005 levels by 2030 . Given the partial substitution of grid-based power, it will be necessary for policy makers to consider: whether write-downs of regulated asset bases of monopoly network providers are necessary; and the appropriate role of monopolists and competitive markets in delivering DER. In relation to climate change, it will be important for policy makers to utilise the current Finkel review and the 2017 Commonwealth review of climate policy to better integrate the electricity and climate change policy streams. The 'energy only' market's operation has been altered through the implementation of legitimate climate change and renewables policies. Therefore, it may be worth thinking through how the impacts of these policies could be mitigated to ensure emissions reductions occur in an orderly and cost-effective manner.

\section{References}

Abbott, M. (2002), 'Completing the introduction of competition into the Australian electricity industry', Economic Papers, Vol. 21, pp.1-13.

Adams, P. Parmenter, B. and Verikios, G. (2014), 'An Emissions Trading Scheme for Australia: National and Regional Impacts', Economic Record, Vol. 90, No. 290, pp. 316-344.

Australian Energy Regulator: AER (2016), Draft: Ring Fencing Guideline Explanatory Statement, AER Publication, Melbourne.

Australian Energy Regulator: AER (2015), State of the Energy Market, AER Publication, Melbourne.

Beder, S. (2003), Power Play: The Fight for Control of the World's Electricity, Melbourne, Scribe.

Beder, S. (2012), 'The real cause of electricity price rises in NSW', The Conversation, 3 September.

Boiteux, M. (1949), 'La tarification des demandes en pointe: Application de la theorie de la vente au cout marginal', Revue Generale de l'Electricite, Translated by H. Izzard in Journal of Business, Boiteux, M. 1960, 'Peak load pricing', Journal of Business, Vol.33, No.2, pp. 157-80.

\footnotetext{
${ }^{21}$ In such a way, the 'unintended consequences' of introducing renewable policies into an 'energy-only' market would be tempered. Alternatively, it may be that policy makers could implement longer-tenor versions of existing supplementary markets (e.g. FCAS market which is evolving in any event) that provide a bankable long-term revenue stream. 
Brown, T., Faruqui, A. and Grausz, L. (2015), 'Efficient tariff structures for distribution network services', Economic Analysis and Policy, Vol. 48, pp. 139-149.

Cambridge Economic Policy Associates: CEPA. (2016), Future Regulatory Options for Electricity Networks, Report prepared for the Energy Networks Association.

Caplan, E. (2012), 'What drives new generation construction? An analysis of the financial arrangements behind new electric generation projects in 2011', The Electricity Journal, Vol. 25, No. 6, pp. 48-61.

Chester, L. (2006), 'The conundrums facing Australia's national electricity market', Economic Papers, Vol. 25, No. 3, pp. 62-77.

Crandall, R.W. and Sidak, J.G. (2002), 'Is structural separation of incumbent local exchange carriers necessary for competition', Yale Journal on Regulation, Vo. 19, Issue 2, pp. 335-411.

Crawford, G. (2015), 'Network depreciation and energy market disruption: Options to avoiding passing costs down the line', Economic Analysis and Policy, Vol. 48, pp. 163-171.

de Biji, P. (2005), 'Structural separation and access in telecommunications markets', CESIFO Working Paper, No. 1554.

Dessus, G. (1949), 'Les principles generaux de la tarification dans les services publics', Union Internationale des Producteurs et Distributeurs de'Energie Electrique, Paper VI, pp 5-20.

Faruqui, A. and Palmer, J. (2011), 'Dynamic pricing and its discontents', Regulation, Fall: pp. 1622.

Fenwick, S., Getachew, L., Ivanov, C. and Smith, J. (2014), 'Demand impact of a critical peak pricing program: opt-in and opt-out options, green attitudes and other customer characteristics', The Energy Journal, Vol. 35, No. 3, pp. 1-24.

Freebairn, J. (2014), 'Carbon Price versus Subsidies to Reduce Greenhouse Gas Emissions', Economic Papers, Vol. 33, No. 3, pp. 233-242.

Freebairn, J. (2016), 'A Comparison of Policy Instruments to Reduce Greenhouse Gas Emissions’, Economic Papers, Vol. 35, No. 3, pp. 204-215.

Goncalves, R. and Nascimento, A. (2010), 'The momentum for network separation: A guide for regulators', Telecommunications Policy, Vol. 34, Issue 7, pp. 355-365.

Graffy, E. and Kihm, S. (2014), 'Does disruptive competition mean a death spiral for electric utilities?', Energy Law Journal, Vol. 35, No. 1, pp. 1-44.

Grattan Institute. (2014), Fair Pricing for Power, Grattan Institute Publication, Melbourne.

Houthakker, H. (1951), 'Electricity Tariffs in Theory \& Practice', The Economic Journal, Vol. 61, No. 241, pp. 1-25.

Howell, B., Meade, R. and O'Connor, S. (2010), 'Structural separation versus vertical integration: Lessons for telecommunications from electricity reforms', Telecommunications Policy, Vol. 34, Issue 7, pp. 392-403.

Jotzo. F. and Loschel, A. (2014), 'Emissions trading in China: Emerging experiences and 
International lessons', Energy Policy, Vol. 75, pp. 3-8.

Jotzo, F. and Mazouz, S. (2015), 'Brown coal exit: a market mechanism for regulated closure of highly emissions intensive power stations', Economic Analysis and Policy, Vol. 48, pp. 71-81.

Mountain, B. and Littlechild, S. (2010), 'Comparing electricity distribution network revenues and costs in New South Wales, Great Britain and Victoria', Energy Policy, Vol. 38, Issue 10, pp. $5770-5782$.

Nelson, T. (2015), ‘Australian Climate Change Policy - Where To From Here?', Economic Papers, Vol. 34, No. 4, pp. 257-272.

Nelson, J. and Simshauser, P. (2013), 'Is the Merchant Power Producer a broken model', Energy Policy, Vol. 53(C), pp. 298-310.

Nelson, T. Reid, C. and McNeill, J. (2015), 'Energy-only markets and renewable energy targets: complementary policy or policy collision', Economic Analysis and Policy, Vol. 46, pp. 25-42.

Nelson, T. and Orton, F. (2016), 'Climate and electricity policy integration: Is the South Australian electricity market the canary in the coalmine', The Electricity Journal, Vol. 29, pp. 17.

Orton, F. and Nelson, T. (2015), 'Relief in sight: Why residential electricity costs in Eastern Australia may fall between 2015 and 2020', Economic Analysis and Policy, Vol. 48, pp. 57-70.

Parer, W. (2002), Towards a truly national and efficient energy market, Commonwealth Government Publication, Canberra.

Pittman, R. (2005), 'Structural Separation to Create Competition? The Case of Freight Railways', Review of Network Economics, Vol. 4, Issue. 3, pp. 1-16.

Pollitt, M. and Haney, A. (2013), 'Dismantling a competitive retail Electricity Market: Residential Market Reforms in Great Britain', The Electricity Journal, Vol. 27, No. 1, pp. 66-73.

Quiggin, J. (1997), 'Estimating the benefits of Hilmer and related reforms', Australian Economic Review, Vol. 30, No. 3, pp. 256-72.

Quiggin, J. (2001), 'Market-oriented reform in the Australian electricity industry', Economic and Labour Relations Review, Vol. 12, No. 1, pp. 126-50.

Quiggin, J. (2014), Electricity privatisation: a record of failure, Report to the Electrical Trades Union, Brisbane.

Riesz, J., Gilmore, J. and MacGill, I. (2016) 'Assessing the viability of Energy-Only Markets with $100 \%$ Renewables - An Australian National Electricity Market Case Study', Economics of Energy and Environmental Policy (EEEP), Vol. 5, No. 1, pp. 105-130.

Schwarcz, S.L. (2014), 'Ring-fencing', Southern California Law Review, Vol. 87, Issue 69, pp. 69-110.

Severance, C. (2011), 'A practical, affordable (and least business risk) plan to achieve $80 \%$ clean electricity by 2035', The Electricity Journal, Vol. 24, No. 6, pp. 8-26. 
Simshauser, P. (2014), 'From first place to last: Australia's policy-induced energy market death spiral', Australian Economic Review, Vol. 47, No. 4, pp. 540-62.

Simshauser, P. (2016), 'Distribution network prices and solar PV: Resolving rate instability and wealth transfers through demand tariffs', Energy Economics, Vol. 54, pp. 108-122.

Simshauser, P. Nelson, T. and Doan, T. (2011), 'The Boomerang Paradox Part 1: how a nation's wealth is creating fuel poverty', The Electricity Journal, Vol. 24, No. 1, pp. 72-91

Simshauser, P. and Nelson T. (2013), 'The outlook for residential electricity prices in Australia's National Electricity Market in 2020', The Electricity Journal, Vol. 26, No. 4, pp. 66-83.

Simshauser, P. and Nelson, T. (2015), "Australia's coal seam gas boom and the liquefied natural gas entry result”, Australian Journal of Resource and Agricultural Economics, Vol. 59, pp. 1-22.

Simshauser, P. and Whish-Wilson, P. (2016), 'Price discrimination in Australia's retail electricity markets: An analysis of Victoria \& Southeast Queensland', Energy Economics, Vol. 62, pp. 92103.

United Nations Framework Convention on Climate Change: UNFCCC. (2015), Adoption of the Paris Agreement, Available online at:

https://unfccc.int/resource/docs/2015/cop21/eng/109r01.pdf, Accessed online on 27 February 2016.

US Supreme Court. (1945), Market St. Ry. Co. v. Railroad Commission.

Whinston, D. (1990), 'Tying, foreclosure and exclusion', American Economic Review, , Vol. 80, No. 4, pp. 837-858. 


\section{Appendix 1: Approach to wholesale electricity modelling}

The emission reduction scenarios have been modelled within the National Electricity Market using PLEXOS ${ }^{22}$ modelling software. The model effectively replicates decision making within the market. Existing generation facilities are 'dispatched' to meet given levels of demand. Over time, new generation capacity can be 'built' and existing capacity retired. Importantly, the capital costs of new generation facilities are included while existing generators incur both short-run fuel and operating costs as well as fixed operating and maintenance expenses. The objective of the model is to minimise total system costs while meeting imposed constraints such as greenhouse gas emission profiles. The model effectively optimises the replacement of higher-cost, more emissions intensive power stations with low emissions generation capacity.

Key assumptions made in the model include:

- $\quad$ Supply must equal demand at all demand points. This ensures 'blackouts' do not occur;

- $\quad$ The minimum reserve requirement must be met in each region;

- New generation cannot be installed instantaneously. As generation takes several years to build, the model requires a commitment to build the generator some years before it can 'generate';

- $\quad$ The current Renewable Energy Target is met through required build of renewable assets (predominantly wind) for all scenarios;

- $\quad$ Emission reduction targets do not apply until 2020 and beyond. This has been adopted to reflect the existing policy landscape;

- Generation capacity is added in realistic increments. For example, individual $1 \mathrm{MW}$ wind turbines are not built to meet incremental emission reduction requirements. This results in 'lumpy' capital investment, which is a key characteristic of energy markets;

- $\quad$ Electricity demand forecasts are derived from the Australian Energy Market Operator (AEMO) official forecasts;

- New entrant cost assumptions are derived from publicly available data sources such as the Australian Energy Technology Assessment and the Australian Power Generation Technology Report;

- The model produces results for the period to 2030. While it is possible to run scenario modelling beyond this timeframe, there are limitations to the validity of the results given the inherent uncertainties of periods so far into the future;

- $\quad$ Fixed costs for multi-unit stations are spread equally across the units. This means that when retiring units, the saving is proportional to the capacity retired and does not reflect that a significant portion of cost may exist at the power station (not unit) level. Therefore, the retirement of units is generally staged rather than all units closing simultaneously;

- $\quad$ No interconnector upgrades are considered;

\footnotetext{
${ }^{22}$ For further information on PLEXOS modelling, see: http://energyexemplar.com/software/plexos-desktop-edition/
} 
- Detailed system security constraints such as those now enforced in South Australia are not included; and

- Coal stations have minimum running levels and are not allowed to cycle on and off. 